\title{
DIE NABYHEID VAN DIE KONINKRYK
}

Vanweë die belangrikheid daarvan volg hier 'n breër bespreking van die proefskrif van $\mathrm{dr}$. Tjaart van der Walt oor die nabyheid van die Koninkryk ') as wat in 'n gewone resensie kan geskied. Die vraagstuk wat onder oë gesien word is so oud as die kerk en die teologie, soms minder en soms meer op die voorgrond. Tans kan gesê word, staan dit in die middelpunt. Daarby is dit nie maar 'n akademiese vraagstuk nie, maar 'n vraagstuk waarvoor elke nadenkende leser van die Skrif te staan kom.

Soos die Koninkryk van God sentraal in die prediking van Jesus, m.n. in die sinoptiese evangelies, so spits die prediking van Jesus aangaande die Koninkryk hom weer toe op die nabyheid daarvan. Daarom kan die vraagstuk van die nabyheid van die Koninkryk nic los gesien word van die greheel van die prediking van Jesus nie. Die studie bestaan dan ook uit twee dele: (1) 'n Breë onderbou van vier hoofstukke (pp. 1-243), waarin agtereenvolgens gehandel word oor die huidige stand van die ondersoek, oor die Koms van die Koninkryk en van die Menseseun, oor die Toekoms soos Jesus dit sien, nl. wat $\mathrm{Hy}$ in die toekoms sien en hoe Hy dit sien, en (2) die toespitsing op die vraagstuk van dic nabyheid van die Koninkryk in die laaste twee hoofstukike (pp. 244-320).

Koms van die Koninkryk en van die Menssesun.

Aangaande die Koninkryk het Jesus gepredik dat dit g.kom het; ${ }^{2}$ ) dat dit nog sal $\mathrm{kom}^{3}$ ) en van 'n tyd tussen koms en koms. ${ }^{4}$ ) Dieselfde geld ook van die koms van die Menseseun: Hy het gekom in nederigheid ${ }^{5}$ ) en Hy sal kom met heerlikheid.6) In verband met die Menseseun is daar egter nog 'n derde groep uitsprake, nl. dat Hy sal kom wat nie by die tweede groep inpas nie en waar sprake is van sy ingaan in die heerlikheid, ${ }^{7}$ ) sy koms in die heerlikheid ${ }^{8}$ ) in die paradys, ${ }^{9}$ ) sit aan die regterhand, ${ }^{10}$ ) aanwe- 
sigheid in die gemeente,"1) sodat aan die hand gedoen word dat by die Menseseun van drie komste gespreck moet word, nl. 'n koms in nederigheid, 'n koms met heerlikheid aan die einde van die dae en 'n (aanstaande) koms tussen koms en koms, d.i. sy toetrede tot die heerlikheid, $\left.{ }^{12}\right)$ terwyl die laaste 'n „brug" (pyler?) vorm tussen die twee en sowel deel is van die eerste (as afsluiting) as van die laaste.

Verder word baie duidelik aangetoon dat die „sien” waarvan daar telkens sprake is by die koms van die Koninkryk en van die Menseseun, ook nie so 'n eenvoudige saak is nie, maar dat by die eksegese (en by die lees) rekening gehou moet word met die verskillende aanskouingsaspek wat saamhang met die verskillende modaliteite van die koms van die Koninkryk en van die Menseseun: Eers 'n sterk gedifferensieerde sien - alleen die wat ö̈ het sicn waarlik; aan die einde 'n universele sien, en tussenin iets van albei - die wat nie oë het nie sien minder ondanks groter magsdade, en die wat oë het sien met groter sekerheid. ${ }^{13}$ ) Die twee soorte sien word ook onderskei as direkte sien, „, sien dat", en indirekte sien, ,insien dat". Die ongelowige en die gelowige sien die verwoesting van Jerusalem. Net die gelowige sien in dat dit die koms van die Koninkryk (Menseseun) is. Die laaste word ook bestempel as „eksistensiële" sien.

Met betrekking tot die koms van die Koninkryk (Menseseun) is die konklusie: (1) clat dit 'n omvattende kompleks is wat begin, voortgaan en tot voleinding kom, cen bew'eging en nie bloot 'n punt nie, met die moontlikheid om vas te stel op watter faset (kragtens die eic aard) van die beweging in bepaalde gevalle die blik gerig word, en (2) onsekerheid wanneer die eindpunt bereik word: God reël die tempo. Die voorwaarde is egter vervul (dic heerlikheidstoetrede) en daarom is daar geen rede vir 'n onbepaalde lang tyd nie.

Elders word die „een beweging" ook beskryf as basies een deurlopende lyn, een omvattende golfslag, maar dan nic 'n egalige, voortskrydende lyn nie. Drie fasette word duidelik onderskei: Die Koninkryk het gekom (in die Persoon en werk van Christus op aarde); die Koninkryk 
sal finaal kom (met sy wederkoms), maar ook in die periode wat hierdie begin en einde skei kom die Koninkryk (in die dood en opstanding van Christus) ,met krag" (Rom. 1:4): die groot gebeurtenis voor die wederkoms. ${ }^{14}$ )

\section{Twee lyne.}

So gereed lê hierdie deurlopende lyn egter nie in die prediking van Jesus nie. As noukeurig nagegaan word wat Jesus (in die toekoms) sien, dan is daar duidelik sprake van twee lyne: (1) 'n Lyn wat gaan tot by die dood en opstanding en daarvandaan verder, ${ }^{15}$ ) en (2) 'n lyn wat deurloop tot by die wederkoms. ${ }^{16}$ ) Op hierdie twee lyne trek die hele problematiek van die toekomsprediking van Jesus saam. Die verskillende groepe waaronder die heersende standpunte saamgebring word, kan onder twce hoofde saamgevat word: (1) Die wat die twee Iyne reduseer tot een, deur inskakeling: Jesus wil die verwagte. maar uitblywende koms van die Koninkryk afdwing deur sy dood (A. Schwcizer en die konsekwente eskatologie), of deur uitskakeling hetsy van die wederkomslyn (C. $\mathrm{H}$. Dodd en die gerealiseerde eskatologie), hetsy van die lydenslyn ( $R$. Bultmann en die transendente eskatologie) en (2) die wat die twee lyne handhaaf (bi-polêre eskatologie). Nou is daar bepaalde uitsprake wat 'n kort tussenperiode in vooruitsig stel. ${ }^{17}$ ) Hier gaan die weë van die laaste groep dan weer uitmekaar: Jesus het die weder koms naby gesien, maar het Hom vergis (Cullmann, Kümmel); gepredik asof dit naby is uit psigologiese oorwegings (Michaelis); naby gesien in die verskvnings ( $\mathrm{K}$. en M. Barth); naby van God se kant (,duisend jaar soos een dag") dan weer ver, van mensekant gesien (Grosheide); naby gesien in „profetiese perspektief” (Ridderbos).

Waar dit in hierdie studie om die nabvhcid van die Koninkryk gaan, kan verwag word dat die nuwe bydrae op hierdie punt gedoen sal word, hetsy in dic vorm van 'n nuwe standpunt wat sal bykom, hetsy in die vorm van 'n nuwe fundering van die een of ander van genocmde standpunte.

Nadere ondersoek van hierdie twee lyne bring tot die resultaat, dat die twee lyne in die toekomsprediking van 
Jesus gehandhaaf moet word. Die bi-polêre eskatologie word dus bevestig. Wat die kort en tussentyd-uitsprake betref is die resultaat, dat in die toekomsblik van Jesus 'n spoedige en 'n latere (laaste) koms onderskei moct word, wat met mekaar in 'n innerlike, saaklike (oorsaaklike) verband staan. Dit is blykbaar die nuwe gesigspunt wat na vore gebring word. Dit is iets anders as, en in sekere sin 'n korrektief op, die sg. „profetiese perspektief" (wat in beginsel wel nie, maar prakties baie naby aan die ,vergissings"-standpunt $\mathrm{kom}$ ): Die twee lyne hang saam - dit val nie saam nic. Dit val nie saam in dic blik van Jesus nie, maar Hy val dit saam omdat dit saamhang. Dit is wat Jesus in dic toekoms sien. Hierby word die blik alreeds daarop gerig hoe Jesus dit sien, hoe Hy daarteenoor staan en hoe Hy dit predik.

Belangrike lig word hier gewerp op die Geskiedenis van die Openbaring. Wat die laaste betref (hoe Jesus dit predik): Die twee lyne, en veral die lydensprediking soos dit kulmineer in die drie bekende lydensverkondigings, ${ }^{18}$ ) lê so ingeweef in die lewe van Jesus, eers in die vorm vall algemene sinspelings, ${ }^{19}$ ) altyd duideliker, ${ }^{20}$ ) in beeldspraak, ${ }^{21}$ ) in uitdruklike uitsprake veral na die cerste iv densaankondiging, ${ }^{22}$ ) dat clit 'n onbegonne taak is om dit uit die geskiedenis uit te lig (soos Bultmann probeer (loen), en dat dic Koninkryk volgens die evangelies klaarblyklik in die geskiedenis gerealiseer is cleur die dood en opstanding van Jesus. Die verweefdheid met die geskicdenis blyk verder ook uit die prediking daarvan as geleentheidsprediking. Die lydenslyn veral toon alles behalwe 'n deurlopende lyn. Dit gaan soms tot by dic (dood. ${ }^{23}$ ) Soms word dic dood en opstanding in die oog gevat, $\left.{ }^{24}\right)$ terwyl dic geskiedenis na sy heengaan gewoon aangaan. ${ }^{25}$ ) Soms word clic lyn getrek tot by die heerlikheidstoctrede.26) Dan word die lyn weer getrek vanaf die opstanding en verder, ${ }^{27}$ ) en bepaald tot by die hemelvaart. ${ }^{28}$ ) Na dic opstanding, d.w.s. wannecr die geskiedenis clie reiliteit van die lewe van Christus na sy sterwe onomstootlik gemaak het, word die lyn deurgetrek in die geskiedenis, ${ }^{29}$ ) en bepaald oor die heerlikheidstoetrede heen tot by Pinkster. ${ }^{30}$ ) Dit alles dra 'n "flitsende", ,kaleidos- 
kopiese" karakter. Hieruit blyk tewens die betroubaarheid van die sinoptiese beriggewing, waarin die versoeking weerstaan is om daarvan 'n geïntegreerde toekomsprogram te maak; verder, dat ons in die evangelies nie met "gewone" geskiedbcskrywing te doen het nie, maar met 'n histories hetroubare weergawe van die prediking en optrede van Jesus, nl. soos dit saamtrek om die lyde (dood en opstanding) en die wederkoms, die twee groot oriënteringspunte in die prediking. Dit weer laat die Openbaringsgeskiedenis sien as nie "gewone" geskiedenis, nie in die sin van 'n geskiedenis wat op 'n ander vlak lê, of geskiedenis van Gods kant gesien nie, maar geskiedenis van sy eindpunt, d.i. eskatologies, gesien, en wel, op grond van die gegewe Openbaring, en so as Openbaringsgeskiedenis, waarin dit gaan om die koms van die Koninkryk, sy tweërlei koms, soos deur Jesus gepredik. Ook in hierdie sin sou dan seker van die nabyheid van die Koninkryk gespreek kan word, en van die Toekoms: Deur openbaring is dit naby gebring, beskikbaar of vervoegbaar gestel (modewoorde!) uit die sfeer van die onvervoegbare tot die vervoegbare en van die onbekende na die bekende, vgl. Rom. $10: 6-8$.

Die prediking van Jesus is situasie-prediking, nie alleen as geleentheidsprediking nie, maar ook in die sin dat dit voor 'n situasie stel, 'n beslissing, ook wat Homself betref: ${ }^{31}$ ) Hy moet na Jerusalem, ${ }^{32}$ ) Hy sal nie alleen sterf nic. Hy moet. ${ }^{33}$ ) Dit is 'n "heilshistoriese", of beter, 'n openbaringshistoriese, moet. Dit is op grond van die Skrifte. ${ }^{34}$ ) Ook só, kan gesê word, is die toekoms saaklik naby. Jesus staan nie teenoor die toekoms as tocskouer nie maar in betrokkenheid en verantwoordelikheid. Dit is ook wcer enigsins eksistensialisties uitgedruk. Tog sou ek die toekomshouding van Jesus nie met die ,modewoord" wil beskryf, nl. dat Hy „eksistensieel” midde-in die toekoms staan nie, alleen al om die rede dat dit 'n toekoms is waaroor $\mathrm{Hy}$ vervoeg, deur openbaring.

Hoe sien Jesus die toekoms? Hy sien dit as deur God bepaal. God rig en lei die geskiedenis. „Slegs wie in hierdie wêreld, in hierdie ruimte leef, kan waarlik begryp wat Jesus oor sy komende lyde, dood en opstanding spreek. 
Want, enkel en alleen vanuit hierdie visie, hierdie werklikheid, spreek Hy". ${ }^{35}$ ) Dit is dan ten diepste die grond waarom die dissipels Hom hierin nie verstaan het nie. $\mathrm{Ek}$ sou dit eenvoudiger wil stel: Die ruimte waaruit hulle en ons moet leef om die toekomsprediking van Jesus te verstaan, ook die prediking van sy eie toekoms, is die ruimte van die Skrifte. ${ }^{36}$ ) Die dissipels het nie verstaan nie, omdat hulle die Skrifte nie verstaan en geglo het nie. ${ }^{37}$ )

'n Belangrike vraag in hierdie verband word verder onder oë gesien: Waarom die twee lyne in die verkondiging van Jesus? Waarom het Jesus dit nie verbind nic? Die volgende verklaring word aan die hand gedoen: Hoe sou Jesus die skandalon van sy lydensweg mag versag deur telkens sy hcerlikheid daaraan te verbind? Feit is egter dat Jesus dit telkens doen, altans die opstanding met die lyde, ${ }^{38}$ ) en ook sy toetrede tot die heerlikheid ${ }^{39}$ ) en die koms met heerlikheid ${ }^{40}$ ) met sy dood. Nooit word egter 'n direkte band gelê tussen die toetrede tot die heerlikheid en dic koms met heerlikheid nie. Die naaste sou wees Matth. $28: 20$ (as uitspraak na die opstanding). Hier word egter nie met sovecl woorde van die wederkoms gespreek nie. Die enigste oorbrugging tref ons aan in die mond van die engel by die hemelvaart. ${ }^{41}$ ) Die antwoord op die gestelde vraag moet wees: Omdat dit twee lyne is. Die een lyn: Deur die dood (en opstanding) tot die heerlikheidstoetrede en daarvandaan verder. ${ }^{42}$ ) Die ander: Deur die dood na die wederkoms. ${ }^{43}$ ) Die dood is die enigste raakpunt tussen die twee lyne. Die dood van Christus is die grond van die verheerliking sowel as van die wederkoms.

\section{Indikatief en Imperatief.}

Die saaklike band tussen hede en toekoms tree duidelik aan die lig in die toekomsprediking van Jesus as geleentheids- of situasieprediking, d.i. waar die lyn getrek word vanuit die hede (van Jesus) na die toekoms. Verrassende lig val daar op die saaklike band tussen hede en tockoms, wanneer dic lyne teruggetrek word van die toekoms na die hede (wat óók kan gebeur in die Geskiedenis van die Godsopenbaring): Die Indikatief (futurum) 
nord Imperatief (praesens). Dit bring die koms van die Koninkryk, hoe naby of hoe ver (in temporele sin) ook al, saaklik in ons onmiddellike nabyheid. Dit laat die toekoms ingryp in die hede en ons aangryp in die hede ons hede. Dit maak die toekomspredikings van Jesus situasie-prediking in die sin dat dit ons voor ' $n$ situasie stel, voor ' $n$ beslissing. Dit geld vir die toekoms van elke individu, ${ }^{+4}$ ) vir die toekoms van Jesus (sy lyde en sterwe, veral) ${ }^{45}$ ) vir die toekoms tussen koms en koms ${ }^{46}$ ) en vir die toekomseindpunt, ${ }^{47}$ ) wat veral vanweë die onbekendheid daarvan ${ }^{48}$ ) in ons onmiddellike nabyheid tree: Elke dag so lewc asof dil elke oomblik kan kom ${ }^{49}$ ) By die gelykenisse van die Onvrugbare Vyeboom ${ }^{50}$ ) en van die Onregverdige Regter ${ }^{51}$ ) tree dit skerp na vore. Die eerste veral laat die hede sien as 'n tyd van respyt, van uitgestelde gerig. Eintlik is die tyd vir die hede al verby. Diz tweede laat die hede sien as 'n tyd van genade en lankmocdigheid, vgl. 2 Kor. $6: 2$ en 2 Petr. $3: 9$.

'n Belangrike studieprojek word hier geopen en aangevoor: „Dic Profetiese Rede in die lig van die Indikatief cn Imperatief", wat dit saambind tot 'n eenheid. Mooi perspektiewe word geopen. Inderdaad vorder die verhouding van die indikatief en die imperatief hier nadere besinning. Dit is 'n vraag of die indikatief (wat God doen) altyd verskyn "by die grasie" van die imperatief (wat ons moet doen). Dit kan ongetwyfeld gesê word by die tockomslyn tussen koms en koms (verdrukkinge ens. as beproewing van die geloof), waar dic indikaticf kontem porêr is met die imperatief. Maar geld dit ook waar die indikatief aan die imperatief voorafgaan ${ }^{52}$ ) of volg?53) Al kom dit in ' $n$ bysin voor, dic bysin is redegewend. Daarom sou ek liewer spreek van 'n imperatief wat rus op die indikatief (van die gekome of die nog komende Konink. ryk) as van 'n deurlopende ,basiese" imperatief.

Verlede, Hede, Toekoms.

Verlede-hede-toekoms lê temporeel en horisontaal uitmekaar maar staan met mekaar in innerlike samehang. Dic band tussen hede, verlede en toekoms is Christus, of ook: Die Koninkryk van God, of, die koms daarvan. Dit 
gaan in die geskiedenis van die Openbaring immers nie oor die wese van die Koninkryk nie, maar oor die koms daarvan, soos aangetoon in die Koninkryksgelykenisse. ${ }^{54}$ ) Verlede is die tyd van die Belofte. Hede, die tyd van Vervulling. Toekoms, die tyd van Voleinding. Of anders: Christus sal kom (verlede); Christus het gekom en sal kom (hede); Christus kom (toekoms). Die hede dra iets van dic verlede en van die toekoms: Vervulling en ver. wagting. Die Christelike tydsindeling sou dan moet wees: Vóor die koms van Christus (verlede); sinds die koms van Christus (hede) en sy wederkoms (toekoms).

Hicruit is tweërlei cluidelik: (1) Tyd is, volgens die Skrif, reële tyd (liniêr) maar ook realisties, d.i. inhoudelike, gevulde tyd met wat daarvoor bestem is, en nie blote verloop nie, en (2) die eindpunt is nie beëindiging van tyd nie maar 'n toekoms, wat reeds begin het met die koms van Christus. Inderdaad is daar 'n tweeslagtigheid in die hede net soos in die lewe van die wedergeborene, 'n ,reeds" en 'n ,nog nie”. Dic toekoms het al aangebreek, die verlede loop in sekere sin nog deur.

Hiermee is reeds gekom by die vier begrippe wat onder ö̈ gesien moet word met die oog op die nadere bepaling van die toekomsperspektief van Jesus.

\section{Die vier begrippe.}

Dit is die begrippe: teken, nabylıeid, tyd en geskiedenis. Hierdie begrippe word elkeen aangewys as studieonderwerpe op hulle self en slegs behandel in soverre hullc lig laat val op die toekomsperspektief van Jesus (hoe Jesus die toekoms sien). Belangrike gesigspunte word hier na vore gebring.

Teken het in die evangelies nie maar net die betekenis van 'n kronologiese voorteken nie, soos in die Joodse apokaliptiek (waarby die transendente eskatologie aansluit). Dit is ook nie die saak self nie (soos by die geraliseerde eskatologie). Dit beteken die anvang van dit wat in aantog is, voordat dit oral en volledig daar is, soos dic somer in sy voortekens, vgl. die Gelykenis van die Vycboom..$^{55}$ )

Hierdie „reeds" en „nog nie" is ook die kern van die 
nabyheids-begrip, waar dit in hierdie ondersoek om gaan. Die moderne betekenis van "naby" is: „tot onmiddellik naby". So verstaan die transendente eskatologie dit. In die Aramees kan dit dieselfde betekenis hê as "gekom". So verstaan die gerealiseerde eskatologie dit. Ons het egter met die Griekse teks te doen. In Grieks kan dit ook hierdie betekenis hê. Uitgangspunt by die eksegese moet egter wees sowel ' $n$,nog nie" as 'n ,reeds", soos duidelik is uit Luk. $21: 20$. Die nabyheidsbegrip bring by die kernwoord van Jesus se prediking, Mark. $1: 15$, Matth. $4: 17$. Die vertaling moes wees "het naby gekom", en nie ,is naby" of "het gekom" nie. Hier word nie 'n tydlose waarheid verkondig nie. Ook word nie 'n historiese feit (aoristus) beklemtoon nie, maar die gevolge daarvan (perfektum). As gevra word: Hoe naby? dan is die antwoord: So naby, dat jy jou nou moet bekeer (indik. perf. gevolg deur 'n imper. praes.). Dit is nabyheid in relasione. le sin, die vanselfsprekende betekenis van nabyheid wat in soortgelyke ondersoeke oor die hoof gesien is en wat die aanleiding was tot hierdie nuwe ondersoek aangaande die nabyheid van die Koninkryk.

'n Vraag kan hier gestel word: Hoe bepaal die indikatief die imperatief hier? Die antwoord moet blykbaar wees: Sowel vanuit die "reeds" as vanuit die "nog nie". Dit is die nuwe situasie.

By die reeds genoemde reële en realistiese in die tydsbegrip van die evangelies moet ook die relasionele kom: Tydsbepalende voegwoorde is die kenmerkende in die tydsbepalinge. Wat voorafgaan en volg is veel belangriker as dag en datum. Die belangrike is nie om te weet wanneer nie maar om gereed te wees as dit kom.

Hierby moet ook beklemtoon word die realistiese (inhoudelike) karakter van tyd. Tyd is nie maar iets wat verbygaan nie, maar tyd vir iets kan verbygaan. Daar is 'n tyd vir en 'n tyd van, die tyd van God se besoeking, die tye van die nasies, ${ }^{57}$ ) ens. Daarom moet die tyd beoordeel word. ${ }^{58}$ ) Hoe moeilik dit ons val om dit te vat blyk uit ons vertaling van Mark. 13 : 19-20: „Daardie dae sal daar verdrukking wees" moet wees "dit sal dae van verdrukking wees, daardie". Tyd word verbind met God. Hy be- 
paal die tye; vul dit met 'n bepaalde inhoud. Daarom is tyd so gewigtig. Verder: AION word sowel vir tyd as vir ewigheid gebruik. Dit beteken al dadelik dat die teëstelling tyd-ewigheid vals is. Dit bring by 'n transendente eskatologie en - hoe baie van ons dink so! As ewigheid nie bó-tydelik is nie, hoe moet ons dit dan sien? Die antwoord moet wees: Tydomvattend. Tyd rus in die ewigheid en bring ewigheidsgedagtes uit soos deur God bepaal vir elke tyd. Dit gee aan die tyd sy inhoud. Dit is die volvoering van God se raadsplan. Maar, hoe realisties of relasioneel ook, tyd bly reëel. Elke moment bevat nie alles nie (transendente eskatologie, wat die wanneer verdring met die wat).

Geskiedenis word gewoonlik verstaan van die mens wat hundel. Geskiedenis is: God wat handel.

Daar is egter 'n andersyds: 'n Mens wat meedoen. Die groot vraagstuk van die geskiedenis is: Goddelike soewereiniteit en rnenslike verantwoordelikheid. Die antwoord (wat hier gegee word) is: God gee (indikatief) en eis (imperatief). Hoe meer Hy gee, hoe meer Hy vra. ${ }^{59}$ ) Die vralag is egter of daar nie ' $n$ inniger verband tussen die gee en die eis van God bestaan nie, nl. dat God ook gee wat Hy vra. Dan is die verbond eers genade-verbond, want verbond is die (regte) verbinding tussen soewereiniteit en verantwoordelikheid. Ons moet dit ook weer so sien: Die soewereiniteit van God (die groot indikatief) omvat die mens (ook die begenadigde) in sy verantwoor. delikheid (die imperatief), sonder om dit te vernietig. Dit is 'n misterie. Maar dit is van betekenis om die misterie te konstateer. Rasionalisering, hier, beteken of skeiding (transendente eskatologie met sy dualistiese geskiedenis. opvatting) of vereenselwiging en vernietiging van die soewereiniteit of die verantwoordelikheid (evolusionistiese geskiedenisopvatting) en, in albei gcvalle, verbondsvernietiging.

By die verklaring van Mark. $13: 16$ val daar weer lig op die Openbaringsgeskiedenis: Die wat insig ontvang in die misterie (van die Koninkryk) is geseënd nie alleen bo hulle tydgenote nie, maar ook bo hulle aan wie God in 
clie verlede sy openbaring gegee het. Daar is dus geskiedenis van die Openbaring.

So 'n lig kon ook geval het op die Openbaringsgeskiedenis vanuit die wese van die geskiedenis. Geskiedenis is God wat handel, en dit bestaan nie alleen in sy allesomvattende voorsienige bestel nie, maar ook in 'n direkte ingrype in die gang van die geskiedenis (sodat dit in die geskiedenis wel staan as besondere feit, maar dan in die geskiedenis), om die geskiedenis tot sy voleinding te bring. Die groot betekenis van ' $n$ wonder is al dat dit 'n wonder is. Die wonderlike ingrype van God het geskied ook van tyd tot tyd en sal weer geskied by die voleinding. Daarom is daar Openbaringsgeskiedenis - ook daarin, clat God openbaar wat Hy doen en sal doen.

Dic geskiedenis loop tiit op dic voleinding. Voleinding en nie be-eindiging nie. Geskiedenis loop nooit af nie, net so min as tyd. Dit kom tot volheid.

\section{Profesic en vervulling.}

Terwyl die hele studie gekenmerk is deur 'n streng metodiese benadering, geld dit van hierdie gedeelte by uitstek. Die metode is om vanuit die vervulling, soos Jesus dit sien, te kom by die wese van dic profesie om dan van die profesie, scos Jesus dit gee, te kom by die vervulling daarvan. Jesus is immers Vervulling en Profeet. Die doel is om by die kern van die toekomsperspektief van Jesus te kom. Die stof wat hier nagegaan word is die lydensaankondiging vanuit hulle vervulling, die verskillende uitsprake van Jesus waarin vervulling van $\mathrm{Ou}$-Testamentiese profesieë verkondig word, ${ }^{60}$ ) die lydensaankondigings as vervulling van Ou-Testamentiese profesieë en ander toekomsuitsprake, waar die moontlikheid bestaan dat Jesus Hom ,doelbew'ys" op bepaalde profesieë beroep ${ }^{61}$ ) of waar dit warskynlik is. ${ }^{62}$ ) Hierdie ondersoek lei dan tot die resultant dat die eieaard van die ,profetiese perspektief" saamgevat kan word in 'n eenheidsformule: 'n Wesensskou - 'n skoue van binne uit, waarin saamgebind word wat in dic vervulling (histories-temporeel) uiteenval. Die band tussen profesie en vervulling blyk ' $n$, intrinsick-kwalitatiewe" en nie (soms "nie soseer" of "cerder 
as") 'n ,uitwendig-kwantitatiewe" (soms afgewissel o.a. met „wesenlik-letterlik") ${ }^{63}$ ) te wees nie. Dit bring tot dic hermeneuliese reël vir profetiese stof in die algemeen en vir die tockomsprediking van Jesus in die besonder, nl. om die intrinsiek-kwalitatiewe in die oog te vat. Die eksegeet moet tevrede wees met die dát (die saaklike), en hom nie bekommer oor dic besonderhede, die hoe, wanneer, wie, nie, tensy hierdie dinge sonder enige twyfel tot die wesenlike behoort, of (wat op dieselfde neerkom): Sien soos Jesus sien. „Die eksegeet moet hom toelê om èn in dic profesie van Jesus èn in die geskiedenis, waarvan hy sell deel is, die wesenlik bepalende te ontdek, en so van binne na buite te leer skou, 'n perspektief wat alleen moontlik is vir hom wat èn die Skrif èn die geskiedenis eksistensieel ken: maar wie dan ook bewus midde in die woord en werk van God staan, kan self nie verbygaan aan dic aanspraak van die hede nie". ${ }^{64}$ ) Dit is ongetwyfeld 'n gewigtige uitspraak hierdic, die hoogtepunt miskien waartoe hierdie ondersoek opvoer: Die sleutel om profetiese stof en m.n. die toekomsprediking van Jesus te ontsluit. Alleen sou ek ,eksistensieel" wil vervang met „essensieel". Dit is tog waarop dit, volgens die ondersoek, op aankom - die wesensskou, en nie 'n verstaan vanuit my bestaan (cksistensie) nie. Maar wat is dan hierdie „essensieele skou"? Dit is ten diepste nie om te sien soos Jesus nie dit sou, as dit heeltemal moontlik was, nog nie verder bring as grammaties-histories ( + psigologiese) eksegese nie, maar om te sien in Christus. Hy is die essensie van die Skrifte (Joh. $5: 39$ ). In Hom is die Ou Testament vervul. Hyself is die sleutel tot die Ou-Testamentiese profesie. Dit is bv. nie so dat Hy gesien het wat gebeur en daaruit algelei het dat Johannes die Doper Elia is wat sou kom nie, $\left.{ }^{6.5}\right)$ maar omdat Hy die Christus is wat sou kom, daarom is Johannes die Doper Elia en die gelowiges die volk van God.

'n Belangrike onderwerp is hiermee aangewys vir nadere ondersoek: „Die noodsaaklikheid van 'n indringende vergelyking tussen die verskillende toekomsuitsprake van Jesus, en 'n veel intensiewer ondersoek na die Ou-Testamentiese voedingsbodem van die woorde van Jesus oor 
hede en toekoms". 'n Belangrike aspek word in hierdie "voorstudie" rceds na vore gebring, nl. dat nêrens in die Ou Testament uitdruklike uitsprake voorkom wat op sy lyde sien en nog minder op sy opstanding. 'n Dringende vaag is: Hoe het Jesus dit aangetoon, vgl. veral Luk. $24: 25-27$. Moet die antwoord nie hierin gesoek word nie, dat die hele Ou Testament en met name die hele geskiedenis van Isracl soos dit saamtrek in ballingskap en terugkeer, ${ }^{66}$ ) profeties op die dood en opstanding van Christus sien nie? Dan is Israel nie alleen Openbaringsvolk in die sin dat hulle draers van die Openbaring was $n e^{67}$ ) maar dat die hele geskiedenis van Israel (dit, wat met hulle gebeur het) openbaring is wat in Christus vervul is.

Die vraag het hom ook telkens na vore gedring of die verhouding profesie-vervulling hom inderdaad laat saamvat in hierdie eenheidsformule: intrinsiek-kwalitatief teenoor uitwendig-kwantitatief (letterlik, ens.). Die vervulling is soms verrassend letterlik terwyl die profesie self geestelike betekenis het, soos blyk uit Matth. 11 : 4 v.v., vgl. Jes. 35 : 4-6. Mens sou dus met ewe veel reg die hermeneutiese reël kon omkeer en sê dat aan die letterlike vasgehou moet word en vergeestelik moet word alleen waar die Skrif self daartoe die reg gee. In ieder geval maan dit tot versigtigheid om die een nie ten koste van die ander te beklemtoon nie. By Mark. 12 : 1-12 word die wingerd verklaar as siende nie minder op Israel as in Jes. 5 nie, maar Israel „anders" beskou, d.i. Israel in sy kern, dit wat sy "wese" uitmaak, d.i. as die ware volk van God. Die vraag is, wat is die verhouding van hierdie ,wesenlike" tot die ,empiriese" Israel? En, wat is die "geheel" wat in die kern gesien word? Is dit die kerk sonder meer, 'n geestelike iets los van die natuurlike? ${ }^{\left({ }^{8}\right.}$ ) Dit bring by die probleem kerk en volk, wat dus saamhang met profesie en vervulling. Hierdie probleem het hom telkens opgedring, veral ook by Mark. $4: 30-32$ (Mostertsaad) $=$ Dan. $\left.4: 9,18 .{ }^{69}\right)$ Is die boom inderdaad maar (algemeen, geestelik) ' $n$ beeld van hoogheid en mag? Ek meen dat ons hier (Mark. $4: 30-34$ ) die Koninkryk moet sien, waarin volkere sal nestel, vgl. Matth. $28: 19$. 
By die ,individuele toekoms" en die "toekoms-eindpunt" tref dit dat dit by die laaste juis gaan om nasies (Matth. $25: 32$ ). Dit is dus nie net die dát (die saaklike) waarop dit aankom nie, maar ook die wié, ens. Wie die "julle" is in Matth. 23 : 39, is van groot belang vir die eksegese daar.

\section{Korttermyn?}

$\mathrm{Na}$ hierdie breë en grondige onderbou, die koms van die Koninkryk, en die Menseseun, die toekoms wat Jesus sien en soos $\mathrm{Hy}$ dit sien, word nou toegespits op die nabyheid van die Koninkryk. Met inagneming van Jesus se hele toekomsblik, van sy konsekwente grondhouding, van die verskillende betekenisse van "sien" en veral van die funksionele betekenis van die betrokke gedeeltes in hulle verband, word op baie oortuigende wyse aangetoon, dikwels teen die gangbare eksegese in, dat die sogenaamde termynuitsprake ${ }^{70}$ ) geen termynuitsprake is nie, maar sien op gebeurtenisse tussen "koms en koms", m.n. sy toctrede tot die heerlikheid, ${ }^{71}$ ) die gerig oor Jerusalem ${ }^{72}$ ) en 'n toekomstige bekering van Israel. ${ }^{73}$ ) Die twee ,termynuitsprake" wat wel op die wederkoms sien, ${ }^{74}$ ) sê aangaande die tydsduur niks nie.

Die grondhouding van Jesus omtrent die dag van sy wederkoms is dat dit onbekend is. ${ }^{75}$ ) Op die vraag wanneer? kan die antwoord maar net wees, ons weet nie.

Die gronddwaling van die heersende rigtings is dat hulle presies weet: Dit het saamgeval met die dood en opstanding van Christus (gerealiseerde eskatologie) of, dit vind elke dag plaas en verder nooit (transendente eskato. logie). Van hierdie heersende rigtings kan nog gesê word dat wetenskaplike ondersoek hom hier beweeg op die terrein van die onmoontlike (non liquet) en die ongeoorloofde (non licet).

Omdat ons die dag en die uur nie weet nie, moet daar egter elke dag mee rekening gehou word. Juis vanweë die onbekendheid daarvan word die toekoms naby gebring by die hede. Die imperatief praesens word daardeur uitermate verskerp (vgl. veral die waaksaamheidsgelykenisse). Nieteenstaande die onbekendheid van die wederkoms, of liewer, juis vanweë die onbekendheid daarvan, 
kan gespreek word van die nabyheid van clic Koninkryk. Die nabsheid van die Koninkryk kan dan omskryf word as 'n moontlikheid," $)$ wat elke dag gerealiseer kan word.

\section{Koninkryksnabyheid.}

By Jesus bly dit egter nic by 'n moontlikheid nie hoe rë̈el ook. By Hom is daar sekerheid.

Vanuit die grondwerk word al die lyne saamgetrek tot die spits. Dit is: Die nabyheid van clie Koninkryk is Koninkryksnabyheid.

Hieronder moet verstaan word (1) 'n nabyheid in ruimtelike, relasionele sin: Só naby, dat die Koninkryk hom onmiskenbaar laat merk in sy voortekens, waarin die saak self aanwesig is, as begin waarvan die einde nie kan uitbly nie, en wel vir die wat oë het om te sien, soos tyciens Christus se optrede; (2) 'n nabyheid waarin die Koning en die Koninkryk self die norm van die termyn is en dit self bepaal, die sekerheid van alle onsekerhede cn (3) 'n nabyheid wat daarin bestaan dat die mens in sy verantwoordelikheid ten nouste daarby betrokke is, ' $n$ futurum indikatief met ' $n$ praesens imperatief, soos in die kcrnprediking van Jesus (Mark. 1 : 15).

Dit is om te sien soos Jesus sien. Ons moet ook soos Icsus sien. En vir wie so sien is niks van die Koninkryk ver nie.

Die ,sien soos Jesus sien" blyk te wees nie om dit wat uiteen lê saam te sien en ineen te sien nie (gewone opvatting van die "profetiese perspektief"), maar in innerlike samehang, ten diepste, van God uit, wat besig is (duratiewe praesens!) om sy heilswerk volgens sy belofte te volvocr. Die koms van die Koninkryk is dan nie één gebeurtenis wat plaasgevind het nie (gerealiseerde eskatologic) of wat sal (of sou) gebeur (konsekwente eskatologie) of gedurig gebeur (transendente eskatologie) of 'n reeks gebeurtenisse wat saamval (,profetiese perspektief") nie, maar wat Jesus saamvat omdat hulle saamhoort.

Hiermee is groot wins te boek ten aansien van bcstaande beskouings. Daar is eenheid in die verskeidenheid en omgekeerd, miskien met groter nadruk op clie eerste. Eensydige nadruk kan die afsonderlike gebeurtenisse aan 
betekenis laat inboet. Ek kon aan die indruk nic ontkom dat die saaklike die temporele te veel oorheers en dat die vervullingsaspek nie genoeg tot sy reg gekom het nie. Om dit wat reeds is, te sien as 'n ,soort antisipasie" of slegs 'n ,vourwerking" van die toekoms in die hede, hoeseer die saak self daarin aanwesig mag wees, is seker nie genoeg nic.

\section{Sien soos Jesus sien.}

Naas hierdie sien soos Jesus sou ck ook 'n ander wyse va! sien soos Jesus wil stel, d.i. om ons terug te verplaas in dic historiese situasie van waaruit Jesus gesien het. Dan het die ,reeds" cn "nog nie" 'n ingrypende verandering ondergaan sinds die dood en opstanding. Wat voor die dood en opstanding, tydens Jesus se optrede, inderdaad naby was, het geskied. Die kronologiese tydsbepaling, ${ }^{77}$ ) veral van die dae en ure by die naderende heengaan van Jesus, is van die grootste betekenis. Dan, die opstanding op die derde dag, sy toetrede tot die hcerlikheid na veertig dae en na tien dae die uitstorling van dic Heilige Gees. Die laaste veral is 'n datum - een datum, in die koms van dic Koninkryk. Van toe af is die Koninkryk blywend hier. So het, wat naby was, gekom. Die grafiese voorstelling, in soverre dit kan dien om lig te wcrp, sou dan wees: 'n Horisontale lyn wat deurloop en twee vertikale lyne wat op twee punte daarop inslaan ${ }^{78}$ ) ,.soos die weerlig".79) In die blik van Jesus val albei in die tockoms, in innerlike samehang, gewis, maar duidelik on(crskei. ${ }^{80}$ ) Ons bevind ons êrens "tussen die tye". Op die cen kyk ons terug. 'n Stuk toekoms, wat vanuit Jesus naby was, het hede geword. Die Koninkryk, soos Jesus dit gesien en gepredik het as naby, is gerealiseer. Die koms van die Koninkryk val uiteen in 'n perfektum en 'n futurum, verbind deur 'n duratiewe praesens. Met die toekoms het ook 'n stuk indikatief futurum 'n indikatief perfektum ${ }^{81}$ ) geword wat die imperatief praesens dra. So vind ons veilig ons weg tussen 'n cskatologiese etiek en 'n eticse eskatologic deur.

Van die aanstaande koms van Jesus en van die Koninkryk kan ook meer gesê word as dat dit (saaklik) 
naby is. Dit is nou (temporeel) nader, ${ }^{82}$ ) veel nader as vir Jesus. ${ }^{83}$ ) Dit gee die onbekendheid van die tydstip nou soveel groter klem as iets wat elke oomblik kan intree, veral in dic lig van dic voorwerking ${ }^{24}$ ) en die vervulling ven die voorwaardes van die wederkoms. ${ }^{85}$ )

Dit kan sekerlik gesê word dat hierdie visie nie ontbreek nie. Deur die sterk nadruk wat die saaklike (intrinsieke) ontvang, kom die suiwer temporele egter enigsins in die skaduwee te staan. Die saaklike en temporele moet nie teenoor mekaar gestel word nie (transendente eskatologie), en ook nie teenoor mekaar gewaardeer word as meerder- en minderwaardig nie. Die Openbaring is histories gegee. Ons moet nie alleen opklim uit die Skrif en die geskiedenis tot die God van die geskiedenis nie. God kom ook tot ons, en het tot ons gekom in die Skrif en die geskiedenis.

Met hierdie vrug van ons jong Afrikaanse teologie sal deeglik rekening gehou moet word by verdere ondersoekinge in hierdie verband. Dit is ook 'n sterk spoorslag tot verdere ondersoek, ook wat die sentrale terna betref die nabyheid van die Kuninkryk.

P.U. vir C.H.O.

W. J. Snyman.

\section{Aantekeninge:}

1) Tjaart van der Walt, Die Koninkryk van God - Naby!, J. H. Kok, Kampen, 1962.

2) Natth. 12:28 (Luk. 11:20); Matth. 11:4 (Luk. $7: 22$ ); Luk. $10: 9$.

3) Luk. 22:18; Matth. 25:31-46; Mark. $24: 27$.

4) In die gelykenisse veral, Mark. 4, Matth. 13, Luk. 8. Hier word ook verwy's na Matth. $12: 28$ (Luk. $11: 2$ ), vgl. Luk. 24 : 49b; Hand. $1: 6$, en na Luk. $17: 24$.

5) o.a. Matth. 11: 19; Luk. 19: 10.

6) Nat:h. 24: 44 par; Luk. $17: 24$ par; Mark. $13: 26$ par; Matth. $25: 31$.

7) Luk. $24: 26$

8) Mark. $3: 38$ volgens gelewerde cksegese - gewoonlik verstaan as siende op dic wederkoms.

9) Luk. $23: 42$

10) Mark. $14: 62$, waar ,kom met dic wolke' vereenselwig word met ,sit aan die regterhand'. Die eksegese is deeglik, maar nıe oortuigend nie. 
11) Matth. $18: 18-20$.

12) Die lyn moet deurgetrek word na Pinkster, wat sowel die bewys van sy toetrede tot die heerlikheid as van die koms van die Koninkryk was, vgl. die prediking van Petrus, Hand. 2 : $16-20,33$.

13) Mark. $14: 62$; Matth. $23: 39$; Matth. $16: 28$.

14) Vgl. aant. 12.

15) Vgl. aantt. 25-30.

16) Vgl. aant. 43.

17) Veral Mark. $9: 1$ par; Mark. $13: 30$ par; Matth. $10: 23 \mathrm{~b}$. Verder ook Matth. 23 : 36; Matth. 23 : 39; Mark. 14 : 25; Mark. $14: 62$; Luk. $18: 8$.

18) Mark. $8: 31$ par; $9: 31$ par; $10: 33,34$ par.

19) Mark. 2 : 20; Mark. 9: 19; Matth. $8: 20$ (Luk. $9: 58$ ).

20) Luk. $9: 31$ (Mark. 9: 12, 13; Matth. 17:13); saamgetrek om dic laaste paasfees, Matth. $26: 18$; Mark. $14: 21$, 26-31; Luk. $22: 37$ en in Gétsemané, Matth. $26: 37$.

21) Luk. $12: 50$ (doop); Mark. $14: 36$ (beker); Mark. $14: 15,41$ (tur); Mark. 2 : 18-20 (bruidegom, wat weggeneem word); Mat th. 12:38-40 (teken van Jona). Mark. $10: 38$ (doop) staan in verband met die wederkoms.

22) Luk. $13: 32,33$; Mark. $10: 45$; Matth. $26: 2$.

23) VgI. aantt. 19-22

21) Lydensaankondigings

25) as 'n tyd van vaste, Mark. $2: 20$, vervolging, Matth. $5: 11,12$; Luk. $6: 22$ v.v.; Matth. $10: 17$ v.v.; Mark. $8: 34$; van evangelieverkondiging, Mark. $14: 8$, 9; van gerig, Luk. 23 : 28-30; bekering van Israel, Matth. $23: 39$.

26) Mark. 9: 1 par; $14: 62$.

27) Mark. $9: 9$.

28) Mark. $14: 28$

29) Matth. $28: 19,20$.

30) Luk. $24: 45-49$; Hand. $1: 8$.

31) Luk. $9: 31$

32) Lydensaankondigings.

33) Lydensaankondigings.

34) Luk. $18: 31-33$, vgl. $24: 27$.

35) pag. 106 vgi. pag. 109 (by die wederkomsvoorseggings): ,00k hier bly dit ten diepste die ruimte waaruit Christus spreek, sy visie op God en die geskiedenis".

36) Dit word as volg omskryf: „die normatiewe van die openbaring van die God van die geskicdenis", pag. 106.

37) Luk. $24: 25$.

38) Lydensaankondigings.

39) Mark. $10: 38-40 ; 14: 25 ; 14: 62$

40) Luk. $17: 24,25$

41) Hand. $1: 11$.

42) Aantt. 25-30. 
43) Duidelikste: Mark. $13: 26$ en Matth. $25: 31$. Verder in orde van duidelikheid: Luk. $17: 24$ (Matth. $24: 27$ vgl. 37); Luk. 18:8b; die Waaksaamheidsgelykenisse (Mark. $13: 35$; Matth. $24: 37$, 42, 46; $25: 6,13,19$ ); Matth. 13: 41; Luk. $17: 22,23$ (Matth. 24 : 26); Mark. 10:35-40; $14: 25$. Mark. $8: 28$ cn $14: 62$ lwort op glond van die gegewe eksegese nie hier nic.

44) Luk. $12: 16-21$ (ryke dwaas); Luk. 16:1-9 (Oneerlike Bestuurder); Luk. 16: 19-31 (Ryk man en Lasarus. Op die vraag of die gelykenis van die Onvrugbare Vyeboom (Luk. $13: 6-9)$ hier hoort word nic ingegaan nie.

45) Lydensaankondigings.

46) Profetiese Rede, Matth. 24 en 25; Mark. 13.

47) Waaksaamheidsgelykenisse, Mark. 13:31-37; Matth. $24: 42-$ $25: 13$, vgl. Luk, $12: 39,40,42-46$; Voleindingsgelykenisse, L.uk. 12 : 35-38 (waaksame dienskncg); Luk. $13: 22-30$ (nou poort); Luk. 14 : 15-24 (groot maaltyd - dit is 'n vraag of dit op die veleindingsmaaltyd sien. Hoe dan met diegene wat uitgewerp word?); Luk. 18 : 1-8 (Onregverdige Regter); Luk. $17: 20-37$ (die ,klein Apokalyps").

48) Mark. 13 : 32; Matth. 24: 36; Hand. 1:6-8; die Waaksaamheidsgelykenisse. Verder: Luk. $17: 20,21$ en veronderstel in Luk. $17: 22-37$ en $21: 34-36$.

49) Dit kom by Bultmann se vertikale eskatologie sterk, hocwel censydig, na vore.

50) Vgl. aant. 44.

51) Luk. $18: 1-8$

52) Matth. $28: 18,19$; Luk. $24: 49$; Hand. $1: 4,5$ vgl. Matth 10 : 19-28; Mark. 13 : 11. Dood en opstanding moet gesien word as die groot imperatief vir Jesus wat 'n heilsindikatief word vir sy dissipels, maar ook vir hulle 'n imperaticf word wat daarop rus, vgl. pag. 132 e.v.

53) Waaksaamheidsgelykenisse, Mark. $13: 33-37$; Luk. $21: 34-36$; Matth. $24: 42-44$ (L.ik. $12: 39-40$ ); Matth. $24: 45-51$ (Luk. 12 : 42-46); Matth. 25: 1-13; verdere Voleindingsgelykunisse by Lukas, $12: 35-38 ; 13: 22-30 ; 14: 16-24$, vgl. Matth. $22: 1-10$; Luk. $18: 1--8$.

54) Matth. 13, Mark. 4, Luk. 8.

55) Mark. 13:28, 29.

56) Luk. $19: 44$.

57) Luk. $21: 24$.

58) Luk. $12: 54,56$.

59) met verwysing na Mark. 4: 11; Matth. 11:27; Luk. 10:22; Luk. $16: 16$.

60) Veral Matth. $11: 10=$ Mal. $3: 1 a, 23,24 ;$ Luk. 4: 17-19= Jes. 61; Matth. $11: 4,5=$ Jes. 35 ; Mark. $12: 1-8=$ Jes. 5 ; Matth. $21: 4,5=$ Sag. $9: 9$.

61) Luk. $21: 22,24$ 
62) Mark. 4: 26-29 vgl. Jona $4: 13 a$; Mark. 4:30-32, vgl. Dan. $4: 9,18$, Escg. $31: 6,17: 23$; Mark. $13: 14$ vgl. Dan. $9: 27$.

63) "wesenlik-intrinsiek" - ,uitwendig-letterlik" of "letterlik".,sigbaar", „basies-letlerlik", ,dieperliggend"-,,oppervlakkig”, ,Iet ter"-,, ,gees", „sigbaar"-,,wesenlik".

64) pag. 242.

65) pag. $214 \mathrm{vgl}$. pag. 314 waar nie alan die indruk ontkom kan word nie dat Jesus uit wat gebeur aflei dat die Koninkryk gekom het en $\mathrm{Hy}$ die Messias is.

66) Vgl. o.a. Ps. 102 : 15-23; Jes. 25-27; Eseg. 37; Rom. 11 : 15.

67) Rom. 3:2; $9: 4$.

68) Vgl. ook by die verklaring van Mark. $7: 1--5$ (Matth. 15: 111) .... die band met die verlede is die sonde van die hede", pag. 170

69) die boom is Nebuhadnesar en die Babilcuiese wereldryk. In Eseg. 31: 6 is dit Egipte en in Eseg. 17:23 Israel.

70) Mark. 9: 1 par; $13: 30$ par; Matth. $10: 23 \mathrm{~b}$. Verder ook: Matth. 23:36 (Luk. 11 : 51b); Matth. $23: 39$ (Luk. 13:35b); Mark. $14: 25$ (Matth. 26: 29, Luk. $22: 16,18$ ); Mark. 14:62; Luk. $18: 8$.

71) Mark. 9: 1 par. vgl. Mark. 14:62. By Mark. 9: 1 (Matth. $16: 28$, l.uk. 9 : 27) moet veral daarop gelet word dat daar staan ,gekom hel" (perfektum).

72) Mark. 13:30; Matth. 10:23b; Matth. 23:36

73) Matth. $23: 39$.

74) Mark. $14: 25$ en Luk. $18: 8$.

75) Vgl. aant. 48.

76) verstaan as 'n objektiewe moontlikheid (erentualiteit) en nie 'n moontlikheid wat subicktief verwesenlik kan word (potensialiteit) nie, soos by Bultmann en die transendente eskatologie..

77) Uit die betreklike skraalheid van dic kronologiese gegewens moct nie gekonkludeer word tot die minder belangrikheid daarvan nie. Dit maak dit juis gewigvol: Die koms van die Koninkryk het datums, vgl, die noukeurige tydsbepaling, Luk. $3: 1,2$. Die Koninkrvk van God het ingegaan in en deel geword van die gewone geskicdenis. Dit het ook 'n datum (gegewenheid) geword.

78) i.p.v. 'n horisontale en 'n vertikale lyn, wat mekaar in die tockoms ontmoct, pagr. 312 .

79) Lak. $10: 18$ (antisiperend op dic toctrede tot die hecrlikheid en dic nitstorting van die Heilige Gees, vgl. Openb. $12: 10$ ) en Matth. $24: 27$.

80) Dic eell raakpunt naby, die ander ver. Die toekomsverwagting van Jesus sou dan nie omskryl moct word as nòg 'n nabye, nòg 'n verre tockomsverwagting (vgl. pag. 169) nie, maar sowel die een as die ander. Dit bevat nie 'n teenstrydigheid nie (vgl. pag 313), want dit het te doen met dic tweërlei koms. 
31) Vgl. by aant. 71 .

32) Vgl. Rom. 13: 11.

83) Omtrent sy wederkoms het Jesus nêrens gepredik dat dit naby is nic. Daar moet inteendeel nog baie gebeur. Dit word deurgaans sterk beklemtoon, rag. 93, 98, $114 \ldots 313$, vgl. ook G. Sevenster, De verwachting van een nabij Koninkrijk in het Nicuwe Testament, Leiden, 1962. Die betrokke gedeeltes is: Mark. 12:9 (wingerd aan ander gegee); Matth. $28: 19$ (al die nasics, rgl. Mark. 13:10); Luk. $21: 24$ (tye van die nasies); Matth. $16: 18$ (gemeentebou, vgl. $18: 15$ v.v.); Matth. $24: 6$ (my heer talm); $25: 5$ (die bruidegom talm); $25: 19$ (lang tycl); $26: 13$ (voortgaande evangelieverkondiging, vgl. Mark. 14 : 9); Luk. $19: 11,12$ (uitdruklik teen die verwagting dat die Koninkryk van God onmiddellik sal verskyn).

84) In die gelykenis van die Vychoom, Mark. 13:28, 29 gaan dit om die voortekens van die wederkoms.

85) Mark. $13: 10$; Matth. $28: 19$ 